Reply

\title{
Reply to Nifli, A.-P. Comment on "Rosell-Cardona et al. Dietary Spray-Dried Porcine Plasma Reduces Neuropathological Alzheimer's Disease Hallmarks in SAMP8 Mice. Nutrients 2021, $13,2369^{\prime \prime}$
}

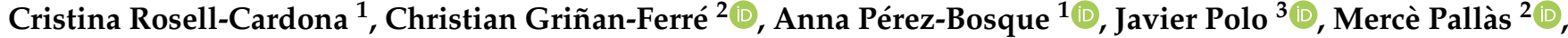 \\ Concepció Amat ${ }^{1} \mathbb{D}$, Miquel Moretó ${ }^{1}$ and Lluïsa Miró ${ }^{1,3, * \mathbb{C}}$
}

1 Department of Biochemistry and Physiology, Faculty of Pharmacy and Food Sciences, Institute for Nutrition and Food Safety, Universitat de Barcelona (UB), 08028 Barcelona, Spain; cristina.rosell@ub.edu (C.R.-C.); anna.perez@ub.edu (A.P.-B.); camat@ub.edu (C.A.); mmoreto@ub.edu (M.M.)

2 Department of Pharmacology, Toxicology, and Medicinal Chemistry, Faculty of Pharmacy and Food Sciences, Institute of Neurosciences, CIBERNED, Universitat de Barcelona (UB), 08028 Barcelona, Spain christian.grinan@ub.edu (C.G.-F.); pallas@ub.edu (M.P.)

3 APC Europe S.L.U., 08403 Granollers, Spain; javier.polo@apc-europe.com

* Correspondence: 1luisa.miro@ub.edu; Tel.: +34-93-4024505

Citation: Rosell-Cardona, C.; Griñan-Ferré, C.; Pérez-Bosque, A.; Polo, J.; Pallàs, M.; Amat, C.; Moretó, M.; Miró, L. Reply to Nifli, A.-P. Comment on "Rosell-Cardona et al. Dietary Spray-Dried Porcine Plasma Reduces Neuropathological Alzheimer's Disease Hallmarks in SAMP8 Mice. Nutrients 2021, 13, 2369". Nutrients 2021, 13, 4065. https://doi.org/10.3390/nu13114065

Academic Editor: Panteleimon Giannakopoulos

Received: 30 September 2021 Accepted: 4 November 2021 Published: 13 November 2021

Publisher's Note: MDPI stays neutral with regard to jurisdictional claims in published maps and institutional affiliations.

Copyright: () 2021 by the authors. Licensee MDPI, Basel, Switzerland. This article is an open access article distributed under the terms and conditions of the Creative Commons Attribution (CC BY) license (https:// creativecommons.org/licenses/by/ $4.0 /)$.
Thank you for your comments on our recent work of the effects of supplementation with spray-dried porcine plasma (SDP) on neuropathological markers of Alzheimer's disease (AD) [1]. The author widely describes the use of blood and blood containing food in different countries and its use in different periods of age, but we would like to point out that SDP is a plasma product, so it does not content the blood cells fraction. Therefore, despite the fact that, as the author indicates, the consumption of raw blood and the SDP supplement improve the barrier function in the intestine [2,3] as well as food digestibility and growth [4], it should be noted that there are large differences between the two products, both in terms of the compounds they contain and in terms of safety.

At the component level, SDP is a complex mixture of many functional components such as albumin, immunoglobulins, transferrin, fibrinogen, growth factors and many other peptides, which can develop a biological activity, not only in the intestine but also at the systemic level, regardless of its nutritional value [5]. Its mechanism of action may involve the interaction of several of its functional components with cells in the body, as well as a prebiotic effect on the intestinal microbiota with anti-inflammatory effects, as observed by Moretó et al. [6].

Regarding the concern for security, it is necessary to mention a couple of aspects to consider. On the one hand, the blood used to produce SDP or serum bovine immunoglobulins (SBI), either from porcine or bovine origin, is obtained from healthy animals declared fit for human consumption after veterinary inspection by the competent authorities. This prevents the collection of blood from sick animals or animals coming from areas of OIE (World Organization for Animal Health) notifiable disease [7].

On the other hand, the manufacturing process of SDP and SBI has been extensively investigated to inactivate microorganism of concern for either human or animal consumption [8]. In case of African Swine Fever virus (ASFV), recent publications [9,10] demonstrated that the different steps involved in the manufacturing process of SDP or SBI (spray-drying and storage at $20^{\circ} \mathrm{C}$ for 14 days) can be considered robust inactivation steps according to World Human Organization (2004) guidelines for human plasma transfusion. Furthermore, with regard to the risk of bovine spongiform encephalopathy (BSE) of prions in the collected blood, in the case of blood from pigs there is no risk of prions diseases because encephalopathies has not been established in natural conditions in commercial 
pigs [11] and, in the case of bovine origin, blood is not considered specific risk material according to the OIE and, in fact, blood and blood products, such as SBI or SDP, are included in the list of safe commodities like milk [12].

Although more studies are needed to understand its mechanism of action, SDP shows neuroprotective effects in the elderly population, increasing brain resilience and reducing neuroinflammation.

Author Contributions: Writing—original draft preparation, C.R.-C., A.P.-B., J.P., L.M., C.G.-F., M.P., C.A. and M.M. All authors have read and agreed to the published version of the manuscript.

Funding: This research was funded by APC-Europe SLU (Granollers, Spain) by research contracts with the Bosch i Gimpera Foundation of the University of Barcelona. The research groups were also supported by grants 2017SGR945 and 2017SGR106 for Consolidated Research Groups, Generalitat de Catalunya, Spain. We also thank Ministerio de Economía y Competitividad of Spain and FEDER funds (PID2019-106285RB) for financial support. CR-C was supported by a grant from the Bosch i Gimpera Foundation (Universitat de Barcelona).

Institutional Review Board Statement: The study was conducted according to the Guide for the Care and Use of Laboratory Animals, and the protocols used in this study were approved by the Ethics Committee for Animal Experimentation of the Universitat de Barcelona and the Catalan government (ref. 484/16 and 9272, respectively).

Informed Consent Statement: Not applicable.

Data Availability Statement: The datasets generated during and/or analyzed during the current study are available from the corresponding author on reasonable request.

Conflicts of Interest: C.R.-C., C.G.-F., A.P.-B., M.P., C.A., M.M. and have no conflicts of interests. J.P. and L.M. are employed by APC-Europe SLU. The funding sponsors had no role in the design of the study; in the collection, analysis, or interpretation of data; in the writing of the manuscript, and in the decision to publish the results.

\section{References}

1. Rosell-Cardona, C.; Griñan-Ferré, C.; Pérez-Bosque, A.; Polo, J.; Pallàs, M.; Amat, C.; Moretó, M.; Miró, L. Dietary spray-dried porcine plasma reduces neuropathological Alzheimer's disease hallmarks in SAMP8 mice. Nutrients 2021, 13, 2369. [CrossRef] [PubMed]

2. Nifli, A.-P. Comment on Rosell-Cardona et al. Dietary Spray-Dried Porcine Plasma Reduces Neuropathological Alzheimer's Disease Hallmarks in SAMP8 Mice. Nutrients 2021, 13, 2369. Nutrients 2021, 13, 4053. [CrossRef]

3. Miró, L.; Amat, C.; Rosell-Cardona, C.; Campbell, J.M.; Polo, J.; Pérez-Bosque, A.; Moretó, M. Dietary supplementation with spray-dried porcine plasma attenuates colon inflammation in a genetic mouse model of inflammatory bowel disease. Int. J. Mol. Sci. 2020, 21, 6760. [CrossRef] [PubMed]

4. Bosi, P.; Han, I.K.; Jung, H.J.; Heo, K.N.; Perini, S.; Castellazzi, A.M.; Casini, L.; Creston, D.; Gremokolini, C. Effect of different spray dried plasmas on growth, ileal digestibility, nutrient deposition, immunity and health of early-weaned pigs challenged with E. coli K88. Asian-Aust. J. Anim. Sci. 2001, 14, 1138-1143. [CrossRef]

5. Campbell, J.M.; Crenshaw, J.D.; González-Esquerra, R.; Polo, J. Impact of spray-dried plasma on intestinal health and broiler performance. Microorganisms 2019, 7, 219. [CrossRef]

6. Moretó, M.; Miró, L.; Amat, C.; Polo, J.; Manichanh, C.; Pérez-Bosque, A. Dietary supplementation with spray-dried porcine plasma has prebiotic effects on gut microbiota in mice. Sci. Rep. 2020, 10, 2926. [CrossRef]

7. OIE. 2021. Available online: https://www.oie.int/en/what-we-do/animal-health-and-welfare/animal-diseases/ (accessed on 9 September 2021).

8. Blázquez, E.; Rodríguez, C.; Ródenas, J.; Rosell, R.; Segalés, J.; Pujols, J.; Polo, J. Biosafety steps in the manufacturing process of spray-dried plasma: A review with emphasis on the use of ultraviolet irradiation as a redundant biosafety procedure. Porcine Health Manag. 2020, 6, 16. [CrossRef] [PubMed]

9. Blázquez, E.; Rodríguez, C.; Ródenas, J.; Rosell, R.; Segalés, J.; Pujols, J.; Polo, J. Effect of spray-drying and ultraviolet C radiation as biosafety steps for CSFV and ASFV inactivation in porcine plasma. PLoS ONE 2021, 16, e0249935. [CrossRef] [PubMed]

10. Fischer, M.; Pikalo, J.; Beer, M.; Blome, S. Stability of African swine fever virus on spiked spray-dried porcine plasma. Transbound. Emerg. Dis. 2021, 68, 2806-2811. [CrossRef] [PubMed]

11. Hedman, C.; Bolea, R.; Marin, B.; Cobriere, F.; Filali, H.; Vazquez, F.; Pitarch, J.L.; Vargas, A.; Acin, C.; Moreno, B.; et al. Transmission of sheep-bovine spongiform encephalopathy to pigs. Vet. Res. 2016, 47, 14. [CrossRef]

12. OIE. 2021. Available online: https://www.oie.int/fileadmin/Home/eng/Health_standards/tahc/current/chapitre_bse.pdf (accessed on 9 September 2021). 